\title{
A Comparative Study of Dermatoglyphic Patterns of Fingers in Normal Children and In Children with Congenital Heart Diseases
}

\author{
Shivaleela $C^{1}$, Nandyal V $B^{2}$, Lakshmiprabha $S^{3}$, Kumar G V \\ ${ }^{1}$ Associate professor of Anatomy. Sri Siddhartha Medical College, Sri Siddhartha Academy of Higher Education, Tumkur, ${ }^{2}$ Professor and HOD of \\ Anatomy. M. R. Medical college, Gulbarga, ${ }^{3}$ Professor and HOD of Anatomy. Sri Siddhartha Medical College, Sri Siddhartha Academy of Higher Education, \\ Tumkur, ${ }^{4}$ Professor of Paediatrics. Sri Siddhartha Medical College, Sri Siddhartha Academy of Higher Education, Tumkur.
}

Abstract

Introduction: Dermatoglyphics is the study of epidermal ridges and their configurations on the palmar and the plantar regions. Currently dermatoglyphics is being used as a tool in the field of biology, anthropology, genetics and medicine to explain, compare and to predict the occurrence of bio medical events. Finger prints are usually categorized into three basic groups namely arches (60-65\%), loops (30-35\%) and whorls $(5 \%)$. Any prenatal insult during this critical period of embryogenesis/organ system development should have an influence on the dermatoglyphic patterns.4Congenital heart defects are a heterogeneous group of diseases in which etiology, importance of genetic as well as environmental factors have been recognized. These defects show a familial tendency but no Mendelian pattern of inheritance has been described. In the present study, finger dermatoglyphic patterns in congenital heart diseases are studied and compared with controls. Subjects and methods: Dermatoglyphics are studied in 100 children with congenital heart diseases, both males and females. The dermatoglyphic patterns of palms and fingers were studied and the information was recorded systematically and statistically analyzed. Results: Ventricular septal defects (VSD) form the majority in the both the males (50\%) and females (34.8\%) in the congenital heart diseases group, followed by Atrial septal defects (ASD) in both males (20.4\%) and females (39.1\%). In both, the cases and controls group, it is found that the majority are loops followed by whorls and then the arches. The increase in whorls in congenital heart diseases is statistically significant with $\mathrm{p}$ value $<0.001$. Comparing the cases with controls it is found that the Whorls $(\mathrm{p}<0.001)$ and the loops $(\mathrm{p}$ $<0.001)$ were statistically significant, it means that the Whorls are more frequently found in congenital heart diseases than the controls. Conclusion: Congenital heart diseases are associated with abnormal dermatoglyphic patterns. Increased number of Whorls and decreased number of Arches are seen in the congenital heart disease children. The above fingerprint pattren may help as a diagnostic aid in diagnosis of congenital heart diseases in children. They may also help in distinguishing congenital heart diseases from the functional and acquired heart diseases. A larger sample study is required to ascertain the value of this dermatoglyphic parameter as a diagnostic tool in congenital heart diseases in children.

Keywords: Dermatoglyphics, Congenital heart disease, Children.

Corresponding Author: Dr. Shivaleela C, Associate Professor of Anatomy, Sri Siddhartha Medical College, Agalakote, Tumkur, Karnataka, India.

Received: March 2019

Accepted: May 2019

\section{Introduction}

DERMATOGLYPHIC originates from the Greek words 'DERMA' which means SKIN and 'GLYPHE' which means to CARVE. Dermatoglyphics is the study of epidermal ridges and their configurations on the palmar and the plantar regions. The fine ridge patterns of the fingers, palms, and soles, have intrigued humans since primitive times. The skin on the palmar and plantar surfaces is grooved by curious ridges, which form a variety of configurations. Papillary ridges are confined to the palms and soles and the flexor surfaces of the digits, where they form narrow parallel or curved arrays separated by narrow furrows. The epidermal ridges correspond to an underlying interlocking pattern of dermal papillae, an arrangement which helps to anchor the two layers firmly together. This arrangement is stable through out life, unique to the individual, and therefore significant as a means of identification. ${ }^{[1]}$

Currently dermatoglyphics is being used as a tool in the field of biology, anthropology, genetics and medicine to explain, compare and to predict the occurrence of bio medical events. ${ }^{[2]}$ Finger prints are usually categorized into three basic groups namely arches (60-65\%), loops (30-35\%) and whorls $(5 \%)$. A person may have the same pattern on all ten fingers but various patterns often occur on different digits. ${ }^{[3]}$ Development of epidermal ridge patterns occurs at 6 th to 19 th week of gestation. Genetic factors alone are not responsible for the development of dermatoglyphic patterns. It is also the result of the interaction between individual genes and the intrauterine environment. Thus, any prenatal insult during this critical period of embryogenesis/organ 


\section{Shivaleela et al; Dermattaglyphic $\mathcal{P}$ atterns of Fingers}

system development should have an influence on the dermatoglyphic patterns. ${ }^{[4]}$ Congenital heart defects are a heterogeneous group of diseases in which etiology, importance of genetic as well as environmental factors have been recognized. These defects show a familial tendency but no Mendelian pattern of inheritance has been described. ${ }^{[5]}$

Whatever the mode of inheritance may be, it is represented by somatic traits such as dermatoglyphics, as supported by some earlier studies showing association of dermatoglyphics patterns with congenital heart diseases by Hale A. R (1961) ${ }^{[6]}$ A Cascos (1964), ${ }^{[7]}$ Brurghat W (1968), ${ }^{[8]}$ Mutalik G S (1968), ${ }^{[9]}$ Magotra M L (1976), ${ }^{[10]}$ Renuka Nair (1986) ${ }^{[11]}$ Brijendra Singh (1996) ${ }^{[12]}$ Anita khalil (1998). ${ }^{[13]}$ In the present study, finger dermatoglyphic patterns in congenital heart diseases are studied and compared with controls. An attempt is made to determine the significant dermatoglyphic parameters criteria applicable to congenital heart disease patients, which can be used as a confirmation test in the diagnosis of congenital heart diseases.

\section{Subjects and Methods}

Hospital based case control study was carried out at Basveshwara Teaching and General Hospital, Gulbarga and Jayadeva Institute of Cardiology, Bangalore. Children having congenital heart diseases (cyanotic and acyanotic) proven by echo-cardiography were included in the study. Children having doubtful congenital heart diseases, acquired heart diseases and deformities of the hand were excluded from the study. Dermatoglyphics are studied in 100 children with congenital heart diseases, both males and females. For each of congenital heart diseases child included in the study, detailed history including consanguinity, birth order of child, drug intake during prenatal period and family history of congenital heart diseases were taken. Electrocardiogram, XRay chest were obtained. A provisional diagnosis of congenital heart disease was made and later confirmed by echocardiography. The control group consisted of 100 healthy children, both males and females, who were thoroughly examined clinically for any other congenital anomalies or having acquired heart diseases. The dermatoglyphic patterns of fingers were studied and the information was recorded systematically

The ridge patterns on the distal phalanges of the fingertips are generally categorized into following groups. ${ }^{[14]}$

1. Arch

2. Loop

3. Whorl

Arch: The ridges pass from one margin of the digit to the other with a gentle distally bowed sweep which gives the name to the pattern type. The plain or simple arch [Figure 1] is composed of ridges which pass across the finger with a slight bow distally. There is no triradius. Tented arch [Figure 2] has a triradius located in or near the midaxis of the digit. The erect distal radiant is associated with abrupt elevation of the transversely curving ridges forming the tent which gives the name to the pattern.

LOOP: It possesses only one triradius. Instead of coursing in complete circuits as in whorl, the ridge course around only one extremity of pattern forming the head of the loop, from the opposite extremity the pattern ridges flow to the margin of the digit. This extremity of the pattern may be considered as open.

If the loop opens to the Ulnar margin it is called an Ulnar loop [Figure 3] and if it opens to the Radial margin it is a Radial loop [Figure 4].

WHORL: The Whorl is regarded as the primitive pattern from which loops and arches are formed, as simplification of design. The majority of ridges make circuits around the core in the pattern area. The Whorl is completely and continuously circumscribed by the type lines. These type lines are radiants extending from the two triradii. This area enclosed by type lines is the pattern area. The type lines are considered as the skeleton of the pattern. That proximal to the pattern area is proximal transverse system and distal one is the distal transverse system. The whorls can present as single pocket whorl [Figure 5] or double pocket whorl [Figure 6]

Descriptive statistical analysis has been carried out in the present study. Results on continuous measurements are presented on Mean \pm SD (Min-Max) and results on categorical measurements are presented in Number $(\%)$. Significance is assessed at $5 \%$ level of significance. The following assumptions on data were made, Assumptions:

1. Dependent variables should be normally distributed,

2. Samples drawn from the population should be random; Cases of the samples should be independent

Student t test ( two tailed, independent) has been used to find the significance of study parameters on continuous scale between two groups Inter group analysis) on metric parameters, Chi-square/ Fisher Exact test has been used to find the significance of study parameters on categorical scale between two or more groups.

\section{Results}

It is a Case-control study consisting 100 congenital heart disease patients and 100 controls undertaken to study the pattern of dermatoglyphics in congenital heart diseases. In this study it is observed that males and females are equal in number both in congenital heart disease and control groups. [Table 1]

Table 1: Gender distribution
\begin{tabular}{|l|l|l|l|l|}
\hline \multirow{2}{*}{ Gender } & Controls & Congenital heart diseases \\
\cline { 2 - 5 } & Number & Percentage & Number & Percentage \\
\hline Male & 54 & $54.0 \%$ & 54 & $54.0 \%$ \\
\hline Female & 46 & $46.0 \%$ & 46 & $46.0 \%$ \\
\hline Total & 100 & $100 \%$ & 100 & $100 \%$ \\
\hline
\end{tabular}

Ventricular septal defects (VSD) form the majority in the both the males $(50 \%)$ and females $(34.8 \%)$ in the congenital heart diseases group, followed by Atrial septal defects (ASD) in both males $(20.4 \%)$ and females $(39.1 \%)$. [Table 2]

Table 2: Diagnosis of congenital heart diseases according to the gender distribution

\begin{tabular}{|l|l|l|l|}
\hline Diagnosis & Total & Male & Female \\
\hline $\begin{array}{l}\text { Ventricular septal defect } \\
\text { (VSD) }\end{array}$ & $43(43 \%)$ & $27(50 \%)$ & $16(34.8 \%)$ \\
\hline Atrial septal defect (ASD) & $29(29 \%)$ & $11(20.4 \%)$ & $18(39.1 \%)$ \\
\hline
\end{tabular}


Shivaleela et al; Dermataglyphic Patterns of Fingers

\begin{tabular}{|l|l|l|l|}
\hline Tetrology of fallot (TOF) & $14(14 \%)$ & $07(13 \%)$ & $07(15.2 \%)$ \\
\hline $\begin{array}{l}\text { Patent ductus arterious } \\
\text { (PDA) }\end{array}$ & $04(04 \%)$ & $03(5.6 \%)$ & $01(2.2 \%)$ \\
\hline $\begin{array}{l}\text { Transposition of great } \\
\text { vessels (TGV) }\end{array}$ & $04(04 \%)$ & $01(1.9 \%)$ & $03(6.5 \%)$ \\
\hline $\begin{array}{l}\text { Double outlet right } \\
\text { ventricle (DORV) }\end{array}$ & $02(02 \%)$ & $01(1.9 \%)$ & $01(2.2 \%)$ \\
\hline Aortic stenosis (AS) & $03(03 \%)$ & $03(5.6 \%)$ & $00(0 \%)$ \\
\hline $\begin{array}{l}\text { Abnormal origin of left } \\
\text { coronary artery from } \\
\text { pulmonary artery } \\
\text { ALCAPA) }\end{array}$ & $01(01 \%)$ & $01(1.9 \%)$ & $00(0 \%)$ \\
\hline Total & $100(100 \%)$ & $54(100 \%)$ & $46(100 \%)$ \\
\hline
\end{tabular}

In both, the cases and controls group, it is found that the majority are loops followed by whorls and then the arches. The increase in whorls in congenital heart diseases is statistically significant with $\mathrm{p}$ value $<0.001$. [Table 3]

Table 3: Comparison of finger pattern analysis in CHD cases and Normal children

\begin{tabular}{|c|c|c|c|c|c|}
\hline \multirow{2}{*}{$\begin{array}{l}\text { Finger } \\
\text { print } \\
\text { patter } \\
\text { n }\end{array}$} & \multicolumn{2}{|c|}{ Controls } & \multicolumn{2}{|c|}{$\begin{array}{l}\text { Congenital heart } \\
\text { disease }\end{array}$} & \multirow[t]{2}{*}{$\begin{array}{l}\text { p- } \\
\text { value }\end{array}$} \\
\hline & $\begin{array}{l}\text { Numbe } \\
\mathbf{r}\end{array}$ & $\begin{array}{l}\text { Percentag } \\
\text { e }\end{array}$ & $\begin{array}{l}\text { Numbe } \\
r\end{array}$ & $\begin{array}{l}\text { Percent } \\
\text { age }\end{array}$ & \\
\hline Loops & 682 & $68.2 \%$ & 537 & $53.7 \%$ & $<0.001$ \\
\hline Arches & 60 & $6.0 \%$ & 48 & $4.8 \%$ & 0.241 \\
\hline Whorls & 258 & $25.8 \%$ & 415 & $41.5 \%$ & $<0.001$ \\
\hline Total & 1000 & 100 & 1000 & 100 & \\
\hline
\end{tabular}

Comparing the cases with controls it is found that the Whorls $(p<0.001)$ and the loops $(p<0.001)$ were statistically significant, it means that the Whorls are more frequently found in congenital heart diseases than the controls. [Table 4]

Table 4: Average Finger pattern in CHD and Normal children
\begin{tabular}{|l|l|l|l|}
\hline $\begin{array}{l}\text { Finger print } \\
\text { patterns }\end{array}$ & Controls & $\begin{array}{l}\text { Congenital } \\
\text { heart disease }\end{array}$ & p-value \\
\hline Loops & $6.82 \pm 2.37$ & $5.35 \pm 2.92$ & $<0.001$ \\
\hline - Ulnar loops & $6.44 \pm 2.36$ & $5.08 \pm 2.84$ & $<0.001$ \\
\hline - Radial loops & $0.38 \pm 0.75$ & $0.27 \pm 0.57$ & 0.243 \\
\hline Arches & $0.60 \pm 1.10$ & $0.48 \pm 1.04$ & 0.429 \\
\hline Whorls & $2.58 \pm 2.43$ & $4.14 \pm 3.23$ & $<0.001$ \\
\hline
\end{tabular}

No statistical significance was found when comparing different finger patterns between the acyanotic and cyanotic heart diseases. [Table 5]

Table 5: Average Finger pattern in CHD of Acyanotic and Cyanotic children

\begin{tabular}{|l|l|l|l|}
\hline Finger print patterns & $\begin{array}{l}\text { Acynotic } \\
\text { congenital } \\
\text { heart disease }\end{array}$ & $\begin{array}{l}\text { Cyanotic } \\
\text { Congenital } \\
\text { heart disease }\end{array}$ & $\begin{array}{l}\text { p- } \\
\text { value }\end{array}$ \\
\hline Loops & $5.20 \pm 2.80$ & $5.95 \pm 3.35$ & 0.306 \\
\hline - Ulnar loops & $4.91 \pm 2.72$ & $5.75 \pm 3.26$ & 0.240 \\
\hline - Radial loops & $0.29 \pm 0.59$ & $0.20 \pm 0.41$ & 0.539 \\
\hline Arches & $0.44 \pm 0.94$ & $0.65 \pm 1.39$ & 0.416 \\
\hline Whorls & $4.33 \pm 3.13$ & $3.40 \pm 3.59$ & 0.254 \\
\hline
\end{tabular}

In the present study, loops and whorls were statistically significant when normal male children compared with male congenital heart disease children. Arches were not significant. [Table 6]

Table 6: Average Finger pattern in Normal and CHD in Male children

\begin{tabular}{|l|l|l|l|}
\hline Finger print patterns & Controls & $\begin{array}{l}\text { Congenital } \\
\text { heart disease }\end{array}$ & $\begin{array}{l}\text { p- } \\
\text { value }\end{array}$ \\
\hline Loops & $6.44 \pm 2.55$ & $5.59 \pm 2.71$ & 0.096 \\
\hline • Ulnar loops & $6.26 \pm 2.49$ & $5.28 \pm 2.65$ & 0.050 \\
\hline • Radial loops & $0.19 \pm 0.44$ & $0.31 \pm 0.61$ & 0.207 \\
\hline Arches & $0.46 \pm 0.95$ & $0.39 \pm 0.86$ & 0.670 \\
\hline Whorls & $3.09 \pm 2.68$ & $4.00 \pm 2.97$ & 0.098 \\
\hline
\end{tabular}

Table 7: Average Finger pattern in Normal and CHD in

Female children

\begin{tabular}{|l|l|l|l|}
\hline Finger print patterns & Controls & $\begin{array}{l}\text { Congenital } \\
\text { heart disease }\end{array}$ & $\begin{array}{l}\text { p- } \\
\text { value }\end{array}$ \\
\hline Loops & $7.26 \pm 2.08$ & $5.07 \pm 3.15$ & $<0.001$ \\
\hline • Ulnar loops & $6.65 \pm 2.20$ & $4.85 \pm 3.07$ & 0.002 \\
\hline - Radial loops & $0.61 \pm 0.95$ & $0.22 \pm 0.52$ & 0.016 \\
\hline Arches & $0.76 \pm 1.25$ & $0.59 \pm 1.22$ & 0.502 \\
\hline Whorls & $1.98 \pm 1.96$ & $4.30 \pm 3.55$ & $<0.001$ \\
\hline
\end{tabular}

In the present study, loops and whorls have significant difference when normal female children compared with female congenital heart disease children. Arches were not significant. [Table 7]

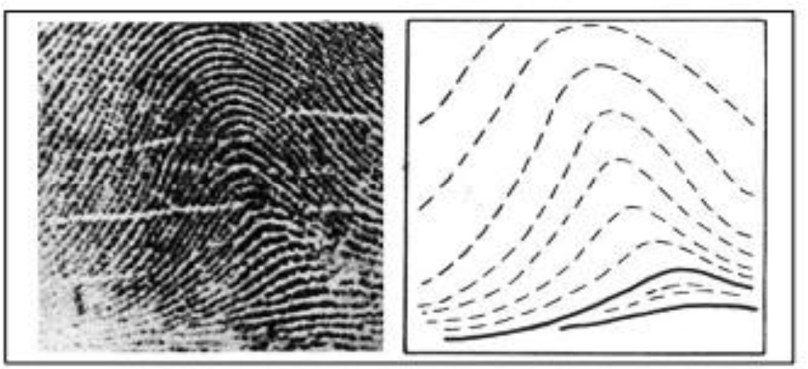

Figure 1: Simple Arch

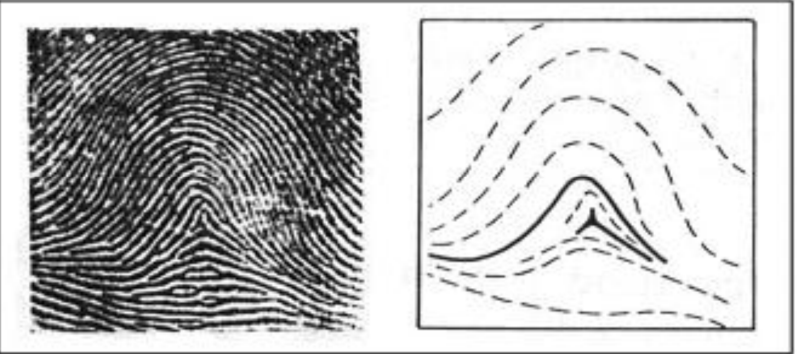

Figure 2: Tented Arch

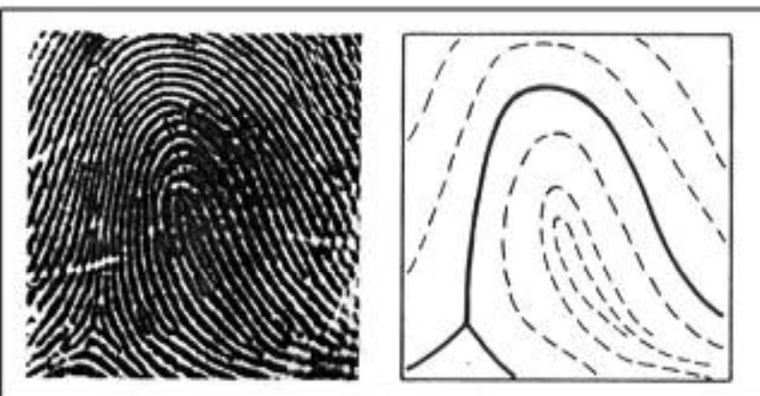

Figure 3: Ulnar loop 


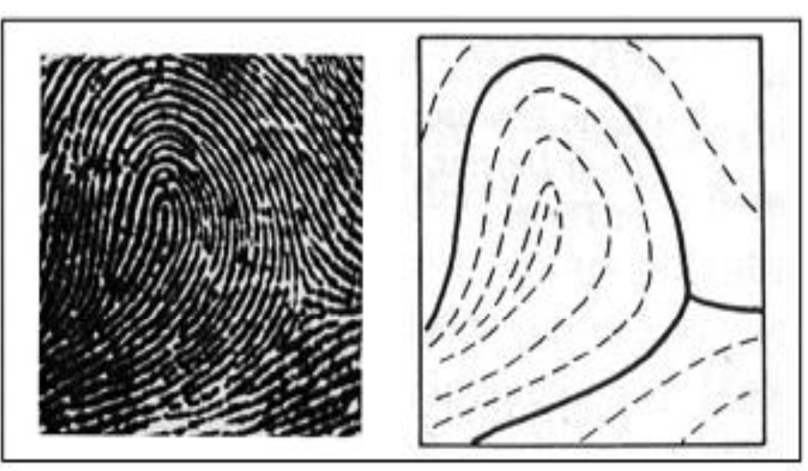

Figure 4: Radial loop

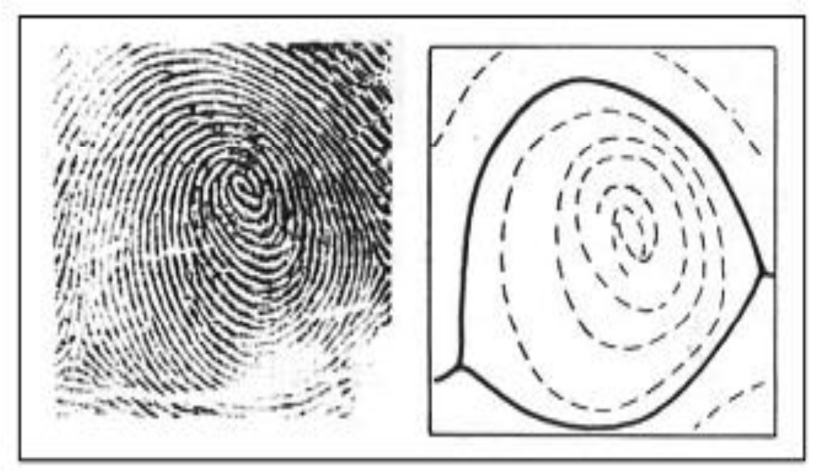

Figure 5: Single pocket whorl

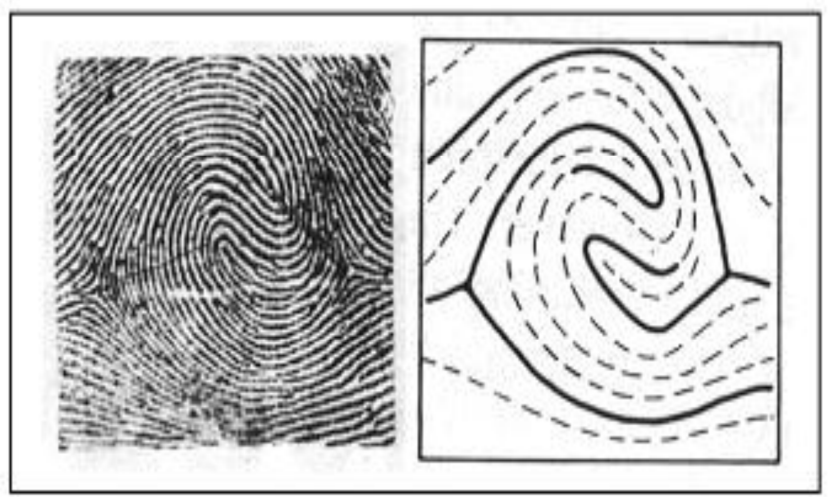

Figure 6: Double pocket whorl

\section{Discussion}

The association of altered dermatoglyphic patterns with various congenital disorders including congenital heart disease was well known, as reported by several workers. In this section an attempt is made to compare the observations seen in our study with previous studies conducted to compare the dermatoglyphic patterns in congenital heart diseases in children.

The present study showed increased numbers of Whorls and decreased numbers of Arches in patients with congenital heart diseases which were in agreement with the studies conducted by Mutalik et al, ${ }^{[9]}$ Magotra M.L. et al, ${ }^{[10]}$ Brijendra Singh et al, ${ }^{[12]}$ and Deepa UT. ${ }^{[15]}$ [Table 8]
Table 8: Comparison of finger print patterns in congenital heart diseases

\begin{tabular}{|l|l|l|l|l|l|}
\hline $\begin{array}{l}\text { Name of } \\
\text { the study }\end{array}$ & $\begin{array}{l}\text { No of } \\
\text { Cases }\end{array}$ & $\begin{array}{l}\text { Ulnar } \\
\text { loops }\end{array}$ & $\begin{array}{l}\text { Radial } \\
\text { loops }\end{array}$ & Whorls & Arches \\
\hline $\begin{array}{l}\text { Present } \\
\text { study }\end{array}$ & 100 & $-^{*}$ & $\mathrm{x}$ & $+^{*}$ & $-^{*}$ \\
\hline Mutalik et al & 12 & $\mathrm{x}$ & $\mathrm{x}$ & $+^{*}$ & $-^{*}$ \\
\hline $\begin{array}{l}\text { Magotra et } \\
\text { al }\end{array}$ & 50 & $\mathrm{X}$ & + & $+^{*}$ & $-^{*}$ \\
\hline $\begin{array}{l}\text { Brijendra et } \\
\text { al }\end{array}$ & 50 & + & $\mathrm{x}$ & $+^{*}$ & $-^{*}$ \\
\hline $\begin{array}{l}\text { Deepa UT et } \\
\text { al }\end{array}$ & 65 & + & $\mathrm{x}$ & $+^{*}$ & $-^{*}$ \\
\hline
\end{tabular}

(+) Increased, (-) decreased, (x) no significant change, $\left(^{*}\right)$ statistically significant

Further analysis of the finger patterns shows, increased Whorls in both males and females of congenital heart diseases group, which is different from the Anita Khalil et al 13 study which showed decreased whorls in both males and females of congenital heart diseases. Most of the study did not show any statistical significance between the male and the female group of the congenital heart diseases.

\section{Conclusion}

Congenital heart diseases are associated with abnormal dermatoglyphic patterns. Increased number of Whorls and decreased number of Arches are seen in the congenital heart disease children. The above fingerprint pattren may help as a diagnostic aid in diagnosis of congenital heart diseases in children. They may also help in distinguishing congenital heart diseases from the functional and acquired heart diseases. A larger sample study is required to ascertain the value of this dermatoglyphic parameter as a diagnostic tool in congenital heart diseases in children.

\section{References}

1. Standring Susan (chief editor): Gray's Anatomy, In Skin and its appendages, 39th edition. Elsevier, Churchill Linvingstone, 2005, 174.

2. Verbov J. Clinical significance and genetics of epidermal ridges--a review of dermatoglyphics. J Invest Dermatol. 1970 Apr; 54(4):261-71.

3. Alter M, Schulenberg R. Dermatoglyphics in congenital heart disease. Circulation. 1970 Jan;41(1):49-54.

4. Balgir RS. Dermatoglyphic features in congenital cleft lip and cleft palate anomalies. J Indian Med Assoc. 1986 Dec; 84(12):369-72.

5. Goldmuntz.E, Clarke B J, Mitchell L E.: The genetic basis of pediatrics heart diseases, Journal of American College of cardiology, 1995; 27: 289-300.

6. Alfred Hale, John H, Philips \& George E Burch.: Features of dermatoglyphics in congenital heart disease, J A M A, 1961; 176: 41-45.

7. Sanchez Cascos A.: Finger prints in congenital heart diseases, British Heart Journal, 1964; 26: 9-11.

8. Brurghat W, Collard P.: Dermatoglyphics in congenital heart diseases, Lancet, 1968; 11:106.

9. Mutalik G.S and Lokhandwala V.A.: Application of Dermatoglyphical studies in Medical diagnosis, Journal of Association of Physicians of India, 1968; 16: 925-932.

10. Magotra M L \& Chakraborti N C.: Dermatoglyphics in Clinical practice, J Ind Ped, 1976; 13:355-358.

11. Nair Renuka R.: Dermatoglyphics diversity in congenital heart defects" Indian Journal of Medical research, 1986; 83: 56-57.

12. Singh Brijendra, Jain Longia, Thomas Kumar P.: Dermatoglyphics 


\section{Shivaleela et al; Dermataglyphic Patterns of Fingers}

in congenital heart diseases, 1996; 45:111-117.

13. Khalil Anita, Gera Rani, Bhuwalka Ashoka, Bharadwaj Shashi.: Asian journal of Pediatric practice, 1998; vol1, no 49:53.

14. Cummins H \& Mildo C.: Finger prints, palms and soles. An introduction to dermatoglyphics, Dover publication. INC, New York, 1961:36-48.

15. Deepa UT, Arasan DG. Dermatoglyphics pattern in children with congenital malformations. Int J Contemp Pediatr 2018; 5:749-53.

Copyright: $\odot$ the author(s), publisher. Academia Anatomica International is an Official Publication of "Society for Health Care \& Research Development". It is an open-access article distributed under the terms of the Creative Commons Attribution Non-Commercial License, which permits unrestricted non-commercial use, distribution, and reproduction in any medium, provided the original work is properly cited.

How to cite this article: Shivaleela C, Nandyal VB, Lakshmiprabha S, Kumar GV. A Comparative Study of Dermatoglyphic Patterns of Fingers in Normal Children and In Children with Congenital Heart Diseases. Acad. Anat. Int. 2019;5(1):82-86.

DOI: dx.doi.org/10.21276/aanat.2019.5.1.19

Source of Support: Nil, Conflict of Interest: None declared. 